\title{
Central Events and Causal Connections: A Narrative-Inquiry Study among Colombian Female Scholars in their Processes as Writers ${ }^{1}$
}

Eventos Centrales y Conexiónes Casuales: Un Estudio de Investigación Narrativa entre Académicas Colombianas en su Proceso como Escritoras.

\section{Bertha Ramos-Holguín and Anna Carolina Peñaloza Rallón ${ }^{2 *}$}

Universidad Pedagógica y Tecnológica de Colombia, Colombia

\footnotetext{
${ }^{1}$ Received: August $9^{\text {th }}$ 2019/ Accepted: April 22 ${ }^{\text {nd }} 2020$

2 Bertha.ramos@uptc.edu.co; anna.penaloza@uptc.edu.co
} 


\section{Abstract}

In the Colombian context there has been an increase in the interest for publishing in high impact academic journals. This is due to various factors such as institutional requirements, hiring requirements, categorization of teachers and academic visibility. The purpose of this researchbased paper, as a decolonial report, is to portray the central events and the causal connections of three female Colombian authors in their process as writers for academic purposes. Data were gathered through in-depth interviews that emphasized on Van Manen's (1997) four lifeworld existential dimensions that include lived time, lived space, lived body, and lived relation. These dimensions helped us uncover the essences of lived experience. Results indicated that central events and causal connections affect the authors' experiences in their process as writers. The key ingredients female authors judge as important events were social interactions with mentors and the context.

Key words: publishing; lived experiences; narratives; decoloniality; academic writing; writing process; academic visibility

\section{Resumen}

En el contexto colombiano se ha incrementado el interés en publicar en revistas de alto impacto. Lo anterior debido a aspectos tales como requerimientos institucionales, requisitos de ingreso, categorización docente y visibilidad académica. El objetivo de este trabajo investigativo, visto como un reporte decolonial, es dar a conocer los eventos centrales y las conexiones causales de tres autoras colombianas en su proceso como escritoras de documentos académicos. La información se recolectó a través de narrativas, registradas mediante entrevistas a profundidad que enfatizaron las cuatro dimensiones de los existenciales del mundo propuestos por Van Manen (1997) que incluyen el tiempo, el espacio, el cuerpo y las relaciones vividas. Estas dimensiones nos ayudaron a descubrir la esencia de las experiencias vividas. . Los resultados indican que existen eventos centrales y conexiones causales que afectan los procesos de las autoras como escritoras. Los ingredientes clave en estos procesos son las interacciones sociales con mentores y el contexto.

Palabras clave: publicación; experiencias vividas; narrativas; decolonialidad; escritura académica; proceso de escritura; visibilidad académica 


\section{Resumo}

No contexto colombiano tem se incrementado o interesse em publicar em revistas de alto impacto. $\mathrm{O}$ anterior, devido a aspectos tais como requerimentos institucionais, requisitos de ingresso, categorização docente e visibilidade acadêmica. O objetivo deste trabalho investigativo, visto como um reporte descolonial, é dar a conhecer os eventos centrais e as conexões causais de três autoras colombianas em seu processo como escritoras de documentos acadêmicos. A informação se coletou através de narrativas, registradas mediante entrevistas a profundidade que enfatizaram as quatro dimensões dos existenciais do mundo propostos por Van Manen (1997) que incluem o tempo, o espaço, o corpo e as relações vividas. Estas dimensões nos ajudaram a descobrir a essência das experiências vividas. Os resultados indicam que existem eventos centrais e conexões causais que afetam os processos das autoras como escritoras. Os ingredientes fundamentais destes processos são as interações sociais com mentores e o contexto.

Palavras chave: publicação; experiências vividas; narrativas; descolonialidade; escritura acadêmica; processo de escritura; visibilidade acadêmica 


\section{Introduction}

M itchell (1996) asserted that "writing is a process of discovering and creating meaning" (p. 39). Effective writing demands a number of things: a high degree of accuracy to avoid ambiguity of meaning; the use of complex grammatical devices for focus and emphasis; and a careful choice of vocabulary, grammatical patterns, and sentence structures to create a style which is appropriate to the subject matter and to the potential reader (Hedge, 2005).

As such, writing is a complex process that entails diverse kinds of knowledge. In fact, as stated by Mur Dueñas (2012), more often than not writing has been marked by more than linguistic structures and rules; it carries with it a history of identity, belonging, and culture. We can even argue that writing is a process of self-discovery and appropriation that is transformative and interactive. In this sense, writing, as stated by Lea and Jones (2011), implies the understanding of institutional systems, familiarity with genres, mastery of processes, etc. In other words, writing is more than just a skill or a competence, it is a culture which is lived differently among individuals and co-created with others.

Scholars usually talk about two kinds of writing: the academic and the private. Academic writing, according to Shannon (2011), is related to any kind of formal written production submitted for academic publication. On the topic of academic writing, Mauranen, Pérez-Llantada, and Swales (2010) coined the phrase "publish in English or perish". For non-native English-speaking countries, publishing in English has become a mark of status and power over publishing in their native language, which could be seen as a representation of the coloniality academic English writing might represent.

Writing in English is meant to increase research visibility and impact, which is why Colombian journals now ask for the abstract to be written in two languages, English and Spanish. Cárdenas (2014) asserted that the increase of publication in academic journals is directly linked with the need to make academic work visible. Additionally, salaries and promotions are also linked to publishing in national and international journals, which will require writing in English. Funding and travel will also depend on the authors' ability to display their research in high standing journals. Furthermore, research groups are ranked on a scale of A1 (being the highest) to $\mathrm{C}$ (being the lowest) based on the academic activity of each group. This includes, among many other aspects, publishing in English.

Quilindo, Calvache, and Delgado (2018) indicated that the dissemination of research results usually occurs when scientific articles are published in peer reviewed journals that utilize statistical methods (biometrics) to analyze the impact of each article. Biometrics helps to find the $\mathrm{H}$-index, which indicates scientific performance 
by analyzing the number of times that an author, publication, or journal has been cited. In such a way, the $\mathrm{H}$-index measures scholars' productivity. In terms of academic journals, the SCOPUS data base has the largest number of citations, which make research articles easy to search for and track by the academic community. Needless to say, more than $80 \%$ of the articles visualized in SCOPUS were written in English. Albarillo (2014) found that $90 \%$ of the articles published in SCOPUS and JSTOR between 1996 and 2012 were in English. According to Albarillo, "Non-English publications do exist but are less visible at the international level, and non-Englishlanguage scholarly indexes exist, but are difficult to discover and relatively unknown in the English-speaking world" (p. 81). Because of this, non-native English-speaking students and professionals are being pushed more and more to publish everything from their undergraduate monographs to laboratory articles in English.

The push toward publishing in English is directly connected to the fact that English has become the lingua franca of research. However, it is worth noting that publishing also requires knowledge in a specific type of English. According to Mauranen, PérezLlantada, and Swales (2010), "Although English is the global lingua franca of academic discourse, most research in academic English is oriented towards the written language, native speakers of English, and the normative tenets of Standard English as used in academia" (p. 638). Consequently, Colombian authors are also expected to accept and utilize Standard English when writing for publication.

Considering the previous, it is essential to understand how Colombian authors are copingwith thepush topublishinEnglish. Morespecifically, itisofdireneedtocomprehend how women, whohavebeen historically underrepresented in academia, live the process of becoming published authors in Colombia. In the following small-scale narrative inquiry ${ }^{3}$ research, three female scholars from a public university in Colombia told their stories about the central events in their process as writers. All three women have published in high standing national and international journals and directed research groups. By asking them to tell their stories about their individual writing processes, we might gain insight on how they became published authors in the English language. We proposed the following research question: What do women's narratives reveal about the central events and causal connections in their process as writers for academic purposes? Therefore, we sought to understand how these women linked "central events" (Omanson, as cited in Trabasso \& van den Broek, 1985, p. 613) to their process as writers.

In order to contribute to our understanding of the lived experiences and the central events of these three scholars, we focused on a deep description of what

${ }^{3}$ Clandinin and Conelly (2000) stated that narrative inquiry is an umbrella term that captures personal and human dimensions of experience over time, and takes account of the relationship between individual experience and cultural context. 
it means existentially to be in the world, as women who are push to write academically in English. This implied achieving a level of abstraction from the data in order to comprehend meanings of particular lived experience. That is why, in the in-depth interviews, we considered Van Manen's (1997) four lifeworld existential dimensions: lived time (temporality), lived space (spaciality), lived body (corporeality), and lived relation (relationality or communality). Temporality accounts for the subjective time in which the experience took place; Spaciality refers to the location or environment of the experience; coeporeality is the sense of the physical self; and relationality is associated with the relationship we maintain with others and how we connect to others and to ourselves in the world.

\section{Literature Review}

\section{Coloniality and Decoloniality in Academic Writing}

Quijano (2000) stated that coloniality deals with the development of capitalism as a neutral process that imposes an Eurocentric classification system. Along the same lines, Ndlovu-Gatsheni, (2018) pointed out that coloniality can be defined as a vertical global power structure, whereby some people enjoy the privileges and benefits of living under modernity and others suffer the negative consequences of the 'darker side' of the same modern world, called 'coloniality'.

Restrepo and Rojas (2010) affirmed that coloniality is maintained alive in books, the criteria for academic performance, cultural patterns, common sense, self-image of people, and aspirations of the self, among many others. The authors further asserted that subjects breathe coloniality all the time and every day. The same authors further stated that there are three main types of coloniality: knowledge, being, and power.

The first, coloniality of knowledge, is based on the insight that colonial societies have systematically vanished other kinds of knowledges, such as indigenous' knowledges and farmers' knowledges. Second, the coloniality of being, is focused on the distinction between superior and inferior human beings based on their race. Certain groups of people can be considered objects, or they can constitute the invalidity of existence. In other words, they can be invisible or naturalized as objects or sub-humans. The third, coloniality of power, is a concept addressed by Quijano (2000), who assured that one of the main axes of power is the social classification of the world's population. This classification is based on a concept of "race" in which people interact in a relationship of inferiority or superiority. In other words, people are socially classified in a hierarchy. Quijano (2000) also argued that this classification aliens with a structure of control that stands on capitalism. It is to say, according to the social classification people are typified, they can be part of the labor force who produce commodities for the 
world market. Meanwhile, other people are part of the dominant group in charge of controlling the labor force.

The push to write in English for academic journals can be seen as a colonial practice. As Kumaravadivelu (2014) stated, intellectuals do not have a choice, rather they have to conform to the Western ways of knowing and as such the way scholars construct their languaging (Maturana, 2007) is mediated by Western structures. In other words, they need to rely on Western narratives to validate their knowledge. As such, this can be considered coloniality of knowledge and power because a single discourse system is being validated. In fact, Mignolo (2011) pointed out that the concept of coloniality of power guides us to understand how the colonialized peoples were subjected to an Eurocentric knowledge system.

That is why this research report serves as an unpacked decolonial perspective (Mignolo, 2011) on what it is to have to cope with colonial practices based on the struggles that the process represents. To address decoloniality, Ndlovu-Gatsheni (2018) mentioned that it produces students and staff members who question the false notions of 'objectivity' and 'universal truths' that enable Western knowledge to project itself as a neutral knowledge. Decoloniality is a way of thinking, knowing and doing as it implies concrete actions. As such, diverse authors acknowledge the importance of addressing diverse strategies to cope with coloniality (Mignolo, 2011; GranadosBeltran, 2016; Maldonado-Torres, 2010; Díaz, 2010). All in all, the previous authors promote a decolonial option that advocates for action-oriented strategies that result in epistemic decolonialization and the re-signification of knowledges.

\section{Gender and Academic Writing in English in Colombia}

Historically, academic writing has been shaped by a long tradition of Western patriarchal ideologies. Standard, native-like English is preferred over other language repertoires. Likewise, the structures and rules of academic writing have been established by the dominant group. In academic writing, we witness the coloniality of knowledge and power. Furthermore, coloniality of being is also present given that women and minorities have been historically excluded and underrepresented in academia. Thus, Western masculine ideologies have traditionally shaped academic writing, thereby, excluding other forms of writing. Hélène Cixous, a French writer, poet, professor, and pioneer of the post-structuralist feminist movement coined the term écriture feminine [feminine writing]. According to Cixous (1976), masculine forms of writing dominated over feminine forms of expression; she wrote the following, 
Let me insert here a parenthetical remark. I mean it when I speak of male writing. I maintain unequivocally that there is such a thing as marked writing; that, until now, far more extensively and repressively than is ever suspected or admitted, writing has been run by a libidinal and cultural - hence political, typically masculine - economy; that this is a locus where the repression of women has been perpetuated, over and over ${ }^{4}$ (p. 879).

From Cixous' (1976) perspective, feminine writing was being oppressed by masculine structures, for which she encouraged women to write about their emotions as a way to free themselves. In academic writing, emotionality and subjectivity are almost always suppressed for objectivity. Much is left to be understood in terms of the impact the colonization of academic writing has had on female scholars and publication. What we do know is that women continue to be underrepresented as grant recipients, first and last position authors, and in high-ranking employment positions. For example, Fine and Shen (2018) looked at the percentage of men and women in the Neuroscience doctoral program at the University of Washington. The number of women enrolled was 55\%, which exceeded the number of men (45\%). However, female representation decreased dramatically in high ranking positions and publications (see Figure 1).

\section{Number of women in neuroscience}

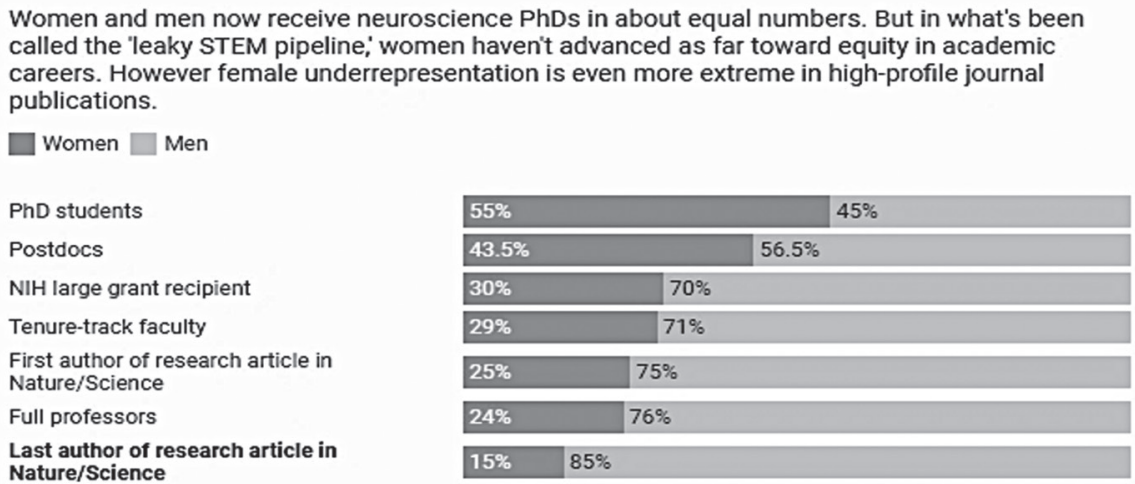

Figure 1. Taken from Fine and Shen (2018).

4 Translation done by Cohen \& Cohen (1976). 
For this study, a database was used to "predict the gender of first and last authors on over 166,000 articles published between 2005 and 2017 in high-profile journals that include neuroscience, our own scientific discipline" (Fine \& Shen, 2018). First and last name author positions are crucial because they mean recognition and visibility. By having fewer women as first and last name authors, the academic community may continue to perpetuate the idea that men are the main participants in all major research. In turn, less visibility also means less probability of being promoted into higher level positions. This holds true for other careers, in which female participation continues to decline after college.

In Colombia, the number of female graduates has surpassed male graduates in the fields of Medicine, Education, Social Sciences, and Accounting (Cepeda \& Barón, 2012). Other fields like Mathematics and Engineering continue to be male-dominated. Nevertheless, the latest statistics released by Colciencias (Colombian Administrative Department of Science, Technology and Innovation) in 2017 demonstrated that 1,072 women were acknowledged as research leaders in the country, which is less than half in comparison to male researchers. Although the percentage of Colombian female published authors is still unknown, we know that researchers' rank is directly connected to their ability to publish in high ranking journals.

Although writing for academic purposes has been a focus for the English as a Foreign Language (EFL) community in Colombia (Anderson \& Cuesta-Medina, 2019; Barletta, 2007; Cárdenas, 2014; Correa \& Echeverri, 2017; Gómez, 2011; Ramos, Quintero, \& Moreno, 2013; Seloni, 2017), very little is understood in terms of the impact Western patriarchal academic writing has had on Colombian female writers and vice versa. Additionally, it is unclear how women, being a majority in many fields, are negotiating and transforming the language and publication process.

Because of this, we took a special interest in working with Colombian women who have published in English. We asked three female scholars at a public university in Colombia to tell us about their writing experiences from childhood to adulthood. We sought to understand the central events that marked their process as writers. Two key aspects differentiate this small-scale research study from others. The first one is that it was a narrative inquiry study, and the second is that writing was seen from a holistic and transformative point of view.

By situating the study from a narrative inquiry perspective, we were acknowledging that each woman had a different story and voice to share. As researchers, our role was to listen and to amplify these voices that have been historically and socially repressed, thereby, uncovering other ways of knowledge, power, and being. As a complement, we chose to listen to all of the women's processes as writers throughout their lives. Doing so meant that the native language and foreign language remained connected as part of a holistic process. 


\section{Methodology}

The following research study was framed under the qualitative approach because it was situated, participant-oriented, holistic, and inductive (Richards, 2009). Specifically, it was situated because it was related to the local realities of each of the narrators, so the conclusions cannot be generalized. It was participant-oriented since the participants were sharing their own realities, which were related to how they interpreted their own writing processes. Additionally, the study was holistic in the sense that it involved a narrative analysis from the perspective of the whole being. We looked at the past, present, and future events in order to understand a historical and socially co-constructed perspective on writing. Finally, the study was inductive given that all the information came from the narrators' voices and not from an initial hypothesis.

In terms of a research paradigm, we situated this study under a critical viewpoint, which states that reality is "shaped by social, political, cultural, economic, ethnic, and gender values", and it is "crystallized over time" (Guba \& Lincoln, 2005, p.198). In other words, we understood that reality was not a finite truth, but rather it was shaped by multiple factors. Likewise, we believe that the research process, the researchers, and the narrators have their own subjectivities. Thus, the aim of this study was not to generalize female authors process as writers, rather it was to display these subjectivities as part of our human nature.

\section{Approaching the Study}

For this study, we utilized narrative inquiry. Narrative inquiry is a way of understanding and inquiring into experience through "collaboration between researcher and participants, over time, in a place or series of places, and in social interaction with milieus" (Clandinin \& Connelly, 2000, p. 20). With narrative inquiry we understood that each narrator had lived their process as writers differently. According to Bamberg (2010), "When narrators tell a story, they give a 'narrative form' to experience. They position characters in space and time and, in a very broad sense, give order to and make sense of what happened-or what is imagined to have happened" (p. 3). In telling the story, the narrator tries to interpret a 'central event' and find causal connections to how one thing led to another. Because of the nature of the narrative, it was impossible for one narrator to tell the same exact story as another.

In order to listen and collect the stories, we followed Van Manen's (1997) four lifeworld existential dimensions. The author suggested that human life entails four fundamental configurations known as existentials. They are time, space, body, and other human beings. These Existential dimensions relate to an approach that helps us comprehend life experiences. In other words, those dimensions allow researchers to uncover human life experiences. 
These existentials guided us in comprehending the data obtained through in-depth interviews. In this sense, we did not intend to categorize, count, search for patterns, or code the data. Instead, we wanted to bring our awareness to some of the experiences lived by three diverse women in their process as writers. In fact, Heidegger (2003) argued that everything in life is a matter of lived experiences. In the case of this study, those experiences were given meaning to deeply comprehend and make sense of the events the authors have lived. We wanted to acknowledge and echo these women's voices because, as Ricoeur (1996) stated, recent narrative researchers have stressed the relevance of voice in the educational field, where the interpretations that the subjects make about themselves become the central focus of investigation.

The in-depth interviews we developed were focused on the following statement: "Tell me about your writing process from the beginning". We emphasized on aspects related to the lifeworld existentials (Van Manen, 1997). Then, we asked about the subjective time or temporary levels in the narrators' experiences (lived time), the feelings they went through and experiences they faced (lived body), the places and spaces where the experiences took place (lived spaces), and the relationships with others and critical people involved in the process (lived human relationships). In this study, we positioned ourselves as women who are part of the academia and who have gone through struggles when writing academic papers in English. We were also aware of the fact that these positions, as stated by Berger (2015), may impact the study. In fact, we noticed that the respondents were willing to share their experiences with us.

Because of our positionalities, we considered some of the principles of reflexivity. According to Berger (2015), reflexivity is the researcher's conscious effort to be attuned to one's own reactions to respondents and the way in which the research account is constructed. Mason (1996) and Porter (1993) explained that reflexivity helps researchers become aware of the potential effects of such positionalities during the process and in the findings of the study.

Each interview was audio-recorded to play it back multiple times. Our focus was on finding instances of 'central events' and their causal connections. A "central event" by definition is both "causal and purposeful" (Omanson, as cited in Trabasso \& van den Broek, 1985, p. 613). For the most part, the narrator will reference and evaluate these events more frequently than 'noncentral events'. Being able to connect 'central events' to an outcome is part of telling a story, which "[is] an important part of narrative discourse structure" (van den Broek, Linzie, Fletcher \& Marsolek, 2000, p. 711). Additionally, we used member checking in which we validated our interpretation by going back to the narrators and sharing the data. In our analysis, we drew out causal chains (Trabasso \& Sperry, 1985) that identified the initiation of the stories, 'central events' connected to each other, and the outcome of the individual's writing processes. 
While most narrative inquiries begin with telling stories, that is, with a researcher interviewing or having conversations with participants who tell stories of their experiences, "a more difficult, time-consuming, intensive, and yet, more profound method is to begin with participants' living because in the end, narrative inquiry is about life and living" (Connelly \& Clandinin, 2006, p. 478).

\section{Participants: The Three Female Scholars}

For this study, we chose three women who had published in English in international Q1 or Q2 journals or in national indexed journals. The three women are full-time professors at a public university in Colombia in the fields of Chemistry and Languages. Additionally, they held high ranking positions at the university, such as being laboratory directors, coordinators, and research group leaders. In the section below, we provided the characteristics that identified each narrator.

Persona $^{5}$ : The Scientist. She has a Ph.D. in Chemistry and has been working at the university for 14 years. She is a laboratory and research group director. She studied her undergraduate and master's in Colombia, and she finished her doctoral studies in the United States. Currently, she conducts research in her field, advises master's and doctoral theses, and teaches undergraduate and master's courses. Most of her publications are in English and have been accepted by Q1 and Q2 international journals.

Mik: The Coordinator. Mik has been working for the university for 14 years. She coordinates several language programs at the university. She supervises about 30 full-time professors and 60 part-time teachers. She holds a master's from the same university, and she also directs a group of young researchers. Apart from her managerial roles, she teaches undergraduate language courses at the university. Mik has published in high standing ELT journals within Colombia. Additionally, she is a poet and writes creative pieces.

Juliana: The Director. Juliana has been working at the university for 12 years. She completed her doctoral studies at the same university. She is a director of postgraduate studies, and she is one of the founders and leaders of a research group in her area. She teaches undergraduate and master's courses, as well as directing numerous monographs, master's, and doctoral theses. Juliana is well-known in her community for her expertise in research and pedagogy. She has co-authored several textbooks and articles on language teaching and pedagogy. She publishes at least once a year in national indexed journals.

${ }^{5}$ The names that appear in this study are pseudonyms provided by the participants. Keeping in mind ethical considerations, all the participants have signed a consent form. 


\section{The Stories}

In the following section, we provided excerpts from our interviews with the three women. We looked at each narrator's story individually as we understood that they would be unique. We also transcribed the stories and chose central events that were recalled by the narrator several times throughout their story. After identifying the central events, we separated the statements within the story with a number. We used discourse markers, such as bueno, porque, entonces, o sea, and $y$ [well, because, so, in other words, and], as guides to separate the statements for causality. In the case that the narrator did not mention a discourse marker, but the statements were dissimilar in intention and meaning, we proceeded to separate them. In other cases, the narrators used discourse markers, but the statements were similar. So, the statements were not separated. Thus, we primarily relied on our evaluation and member checking to separate statements for causality. To visually represent the data, we drew causal chains (Trabasso \& Sperry, 1985) to indicate causal connections between statements. Circled numbers represent statements that lead to a conclusion, while unclosed numbers were statements that had no concluding result. Statements on the same line indicate temporal, or lived time, similarities.

\section{Results}

\section{Persona: The Scientist}

Persona began by telling us the issues in research and writing within Colombia and the sciences. She mentioned three key problems, which she continually refers to throughout her narrative: belief of insignificance, belief of grandeur, and lack of resources. She explained the first issue as,

[So that little bit that you are applying, like what for? It is like nothing. I think this is called the insignificance of the Hispanics]. (Persona, Personal interview)

She believed that the first hurdle in writing in English was the feeling of irrelevance that Spanish speakers face when publishing and writing in English. She referred to the second hurdle, belief of grandeur, as the idea that only top scientists in the field can publish. Finally, the lack of resources, such as laboratory equipment, reagents, and funding, limit the quality of research and results obtained.

We were able to identify a central event that Persona referred to several times, which was her experience in her doctoral program in the United States. She mentioned her laboratory director as a key agent in her story. The figure (Figure 1) and story below showed the causal connections she made between her initiating statement in line 19 and her conclusion line 41. 


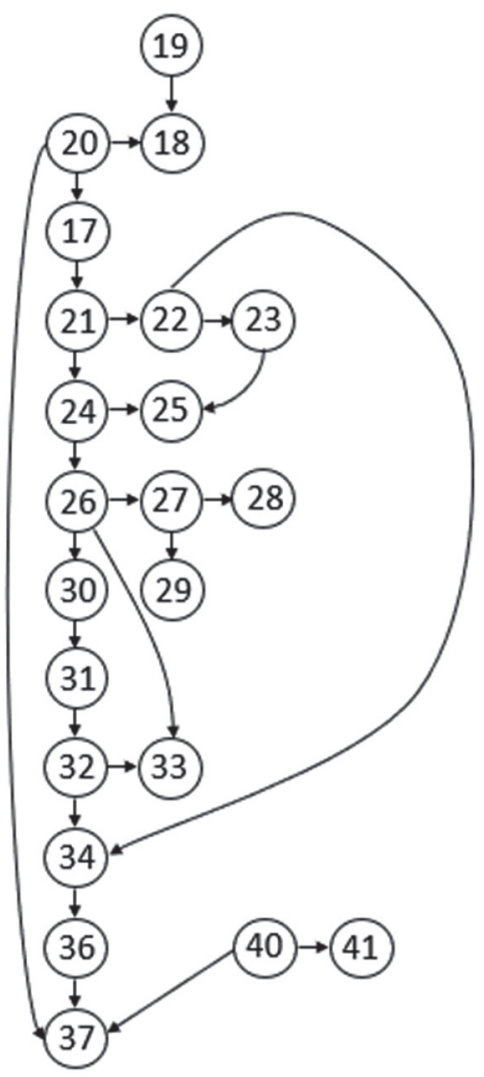

Figure 2. Persona's causal chain showing the connection of events in her doctoral program experience

17 Entonces yo había escrito un articulo

18 yo creo que soy unas de las pocas personas que yo hago proyectos Colciencias y no publico

19 así me hayan dado plata para escribir un libro

20 porque primero pues qué va a aportar, como nada

21 y quien me lo hizo cambiar, mi jefe en Estados Unidos

22 que me hizo ver, mira, que es lo importante, si tú tienes un hilo conductor tú no puedes hacer unos experimentos solo porque tú sabes hacer cosas, unos experimentos como yo voy a mezclar aquí, voy a subir allá, ¿sí? Como desordenados, o desorganizados más bien 
23 porque ellos pueden tener cierto orden, pero no tienen ninguna orientación, o sea como desorganizados, sin una orientación, o un punto final

24 entonces lo que él me dijo fue: lo primero que vas a hacer es una idea, o sea yo tengo una idea, yo hacía unos experimentos

25 pero sin hilo conductor, o sea, desorganizados, sin un fin

26 entonces el que me dijo lo que tú vas a hacer es que vas a hacer, te vas a imaginar cuáles son las figuras que quieres tener allí, la figura 1, la figura 2, la figura 3 (dibuja ejemplo de figuras en un papel)

27 claro, yo en Estados Unidos tenía todo el equipo que yo quisiera,

28 entonces allá yo me podía imaginar cuanta locura y era perfecto, ¿sí?

29 porque usted tiene todo

30 entonces qué hacía yo, entonces ya con esto yo le daba un orden

31 y él me ayudaba organizar, como, okay, entonces vas a hacer esto, pero esto no me está saliendo, como muy, o sea pues sí, pero como que no

32 entonces me decía a través de esto vas a hacer otro experimento

33 y vas a ver que esta figura mejoró, ¿̇í?

34 él me enseñó a pensar así

35 entonces yo ahora como pienso con mis estudiantes

36 entonces bueno, entonces yo así logre escribir cinco papers en Estados Unidos

37 de los cuales no he publicado el primero

38 pero a mi realmente, hay otra cosa, eso no lo tiene todo el mundo, pero yo me ha dado cuenta de que la mayoría de investigadores somos así,

39 pero no solamente los colombianos, o los hispanos, por creernos como menos cosa, si no en general.

40 yo vi eso en los hindúes, vi eso en muchos americanos de ciencia

41 allí está el paper, pues se publicará cuando se pueda. Eso, cuál es el afán. ¿¿Sí? porque nosotros hacemos investigación

Persona began with the first time she published an article. She did not expand on this, rather she talked about how she failed to publish her work, which she attributed to her belief of insignificance. She then mentioned her laboratory director as the agent who changed her way of thinking. His role in teaching her how to tell the 'science story' in her papers is fundamental in organizing her research. In fact, her director's contribution released a causal chain reaction of organization, planning, editing, and revision of her work (lines 24, 26, 30, 31, 32, 34, 36, \& 37). 
One important aspect in Persona's narrative was that despite her director's key role in changing her way of thinking (line 21), she mentioned that she did not publish any of the five papers that she had written. Because of this, her initial beliefs outweighed her director's significant influence. However, in listening to the rest of her narrative, we found that her director had shaped her tremendously in the way she organized her research. She mentioned in line 26 that her director had told her to imagine the figures she wanted to see in her research. These figures referred to the methods of research, such as Gas Chromatography (GS), Scanning Electron Microscopy (SEM), and Transmission Electron Microscopy (TEM).

Even though she lacked all of the methods of research she had in the United States, she still adapts this idea of organization in her context. Furthermore, she mentioned in line 35 that this is how she teaches her students. In the interview, she stated that she uses the figures method to organize her research and papers, but the context limits her use of SEM and TEM due to their high cost. Therefore, she and her students must adapt to the context, which ultimately leads to a less rich discussion in the research and article. Toward the end of her story, Persona revealed a final reflection on the publication process. In line 38 , she mentioned that the delay in publishing papers is not necessarily connected to a feeling of insignificance among Spanish speakers. Rather, she witnessed that other researchers from different nationalities (lines 39 to 40) lacked an immediate need to publish in English since researching was more important. Based on Persona's narrative, we see that her inhibition to publish comes from personal and outside factors. From a personal point of view, Persona feels her research and writing is insignificant. Meanwhile, she prefers research over publishing her work. However, her lack of resources also inhibits the quality of her and her students' results, which diminishes the type of journals she can publish in.

\section{Mik: The Coordinator}

Mik began by stating that she had always liked to write. She mentioned this at least five times in her initiation. She continued to talk about writing from a structured standpoint, such as mentioning organization, APA guidelines, and coherence. However, she later opened up about her writing ability and interest. In doing so, we were able to identify a central event in her life as a writer: her father's poetry readings. Figure 2 shows the causal connections in Mik's story about her father. 


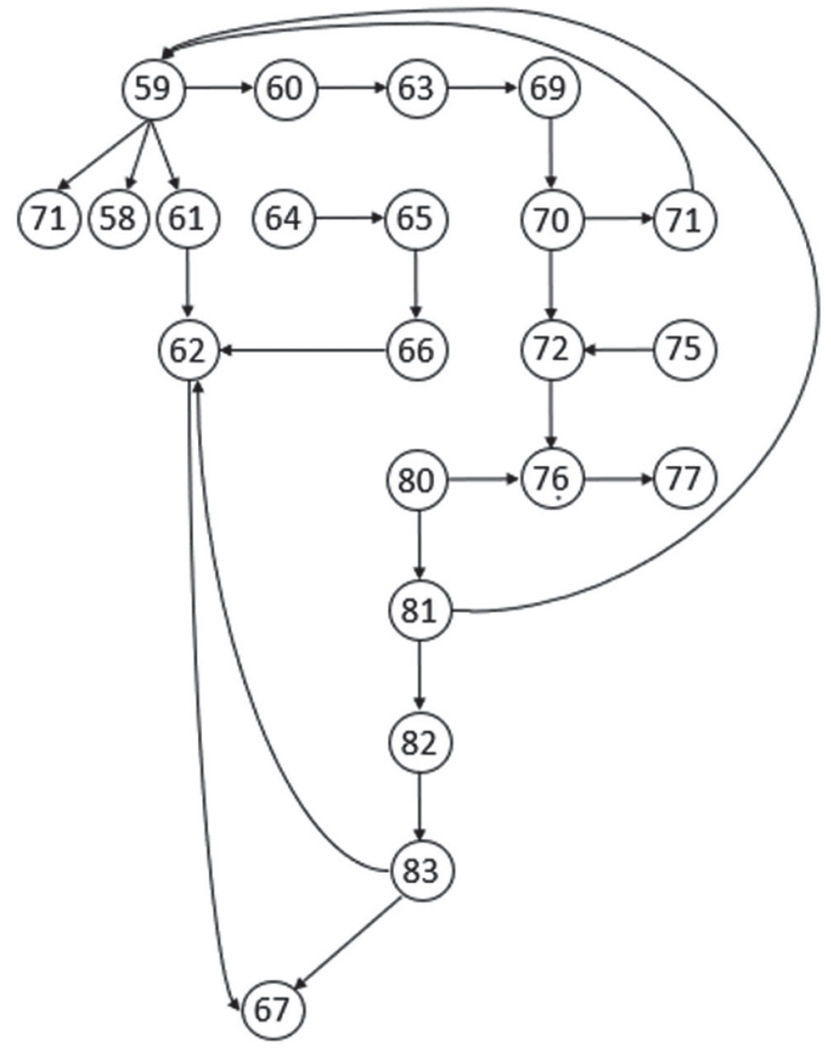

Figure 3. Mik's causal chain showing the connection of events in her father's poetry reading

58 Sí, sí. Mire que yo le admiraba eso a mi padrecito

59 decía mucha poesía. ¿Sí?

60 nos sentaba y nos decía

61 y yo (gasp) yo lo admiraba. Yo decía tan bonito

62 tal vez saqué muchas cosas de mi papi

63 porque mi papi le gustaba muchos los idiomas

$64 \mathrm{mi}$ papá sabia varios idiomas 
65 él tenía muchos libros de varios idiomas

66 y nos leía

67 por eso fue que como yo dije, (gasp), muestre me gusta como los idiomas, me gusta como los idiomas

68 porque él nos leía

69 y tenía muchas cosas, y yo uuuy tan bueno

70 los papás saben mucho

71 mi papá yo lo admiraba y lo admiro todavía.

72 él era como una enciclopedia andante

73 y él también me enseñó a trabajar, a manejar la máquina de escribir

74 él me enseñaba, tenía su maquinita

75 y me la prestaba

76 y me dictaba oraciones el toto tororoto toma tinto en un tintero (laughs) y una cantidad

77 y al cabo de un instante se deslizaban por su superficie de las aguas azules

78 y entonces aprendía

79 y cogía agilidad

80 pero fíjate que allí está la poesía, por ejemplo ese pedacito

81 y él decía cosas tan bonitas

82 entonces como que le prende a uno eso

83 y yo también como que quería hacer lo mismo

Mik recalled her father reading to her and her siblings twice (lines $66 \& 68$ ). In her story, Mik mentioned that she admired her father because he read to them (lines 58, 61, \& 71). As she described her father, she mentioned several statements that were temporally connected rather than causative. For example, her father sitting his children down (line 60), liking languages (line 63), and having many things (line 69) were all temporally connected. In lines 74 and 75, Mik told us about how her father taught her how to use the typewriter. Lines 76 and 77 are poetic verses that her father would read to her while she typed. She mentioned that this exercise helped her learn (line 78), which in turn caused her agility in working the typewriter (line 79). It is in line 80 that she mentioned that the poetry was in her father's verses. Eventually, her father's verses resulted in awakening the love for poetry in her (line 82). The final conclusion was that she wanted to be like her father (line 83), which led to her choice in becoming a language teacher (line 67). 
From Mik's narrative, we could see two contrasting ideas. The first is her presentday structured way of writing. She emphasized the organization of the text, APA guidelines, and vocabulary as necessary in publishing a paper. However, Mik's history with writing is less connected to the rigorous structures of language and more with the fluidity and rhythm of her father's poetry. Based on her admiration for her father (line 50), Mik acquired many of the things that represented him, such as a love for poetry, languages, and writing. From her causal chain, we were able to interpret that agents, such as her father, play a profound role in developing one's interest in writing at a young age. Nevertheless, Mik exemplifies the coexistence of two different but simultaneous worlds, that of being a structured writer for academic purposes while maintaining her poetic side inspired by her father.

\section{Juliana: The Director}

Juliana's writing process was marked by four central events. Her story was unique in the sense that she told a direct sequence of events beginning from childhood. Three of the four central events had a negative cause and effect relationship. We found it admirable that despite the multiple negative causalities, she had an overall positive perspective on writing and publishing. From her narrative, we identified the following central events: when Juliana learned to read as a child, the verbal abuse she faced as a fifth grader, her disappointment in her literature class, and when she published her first paper.

The first central event focused on her childhood when she was in kindergarten. She could not read, which was something she associated with not being able to write. Because of this, her kindergarten teacher told her mother that if she did not read, she would not pass the school year. The effect was that her mother gave her a newspaper, which Juliana ended up reading on her own. From this first central event, we identified two key agents: the kindergarten teacher and mother. We also identified motivational causality in the first event given that her teacher's discourse motivated the narrator's mother and narrator to reach a goal: to read (see Annex 2).

The second central event was the most traumatic. In fact, the narrator referred to this event several times throughout her story. In fifth grade, she was hit and verbally abused by her teacher because her teacher believed she had horrible handwriting. This event unleashed a causal chain related to her teaching practices today. She explained that despite her age, she still recalled this episode. In line 18 (see Annex 2), she related this event to having marked her writing. In addition, she avoids writing on the board (line 19), brings printed handouts (line 21), uses the computer (line 22), and apologizes when she writes on the board (line 24). Later, she mentioned this event once more when she concluded her story about her first published paper. She said, 
[because before this, I think that the things I wrote were the letters I wrote my mom with spelling errors] (Juliana, Personal interview)

After nine statements, the narrator continued to explain her fifth-grade event, which she concluded in line 97 by saying,

[I think those first steps really marked me] (Juliana, Personal interview)

Interestingly, we see how the act of writing itself, as in handwriting, and reading are directly connected to a process of writing. The third central event was related to her undergraduate program. She had anticipated her literature class, and she associated this class with being able to write and write from the self. Unfortunately, her teacher verbally abused the class. Due to this event, the narrator mentioned that she told her students she disliked literature. In addition, she attributed this event as the cause for being unable to write as a means to express herself. She added the following,

[I did not write. In other words, I did not develop that writing part] (Juliana, Personal interview)

In this case, Juliana makes a distinction between academic writing and creative writing, both of which she mentioned could be developed. The final central event was the moment she began to publish and write in English. We mapped out the causal chain for this event in Figure 4. Her process began when she entered the master's program (line 43), which was a different experience than her previous events because they appreciated her work (line 47). She had to complete a small-scale research project (line 50) for her professor, which motivated her need to write a paper (line 53). She went back in her story to explain a critical time within her context. The narrator mentioned that at the time, English journals in her field were nonexistent or unknown (lines 55 \& 56). This statement was temporally connected to her studying the master's (line 43), though they were not causally connected. Nonetheless, they were both independent causes for her writing and publishing her first paper (line 85). 


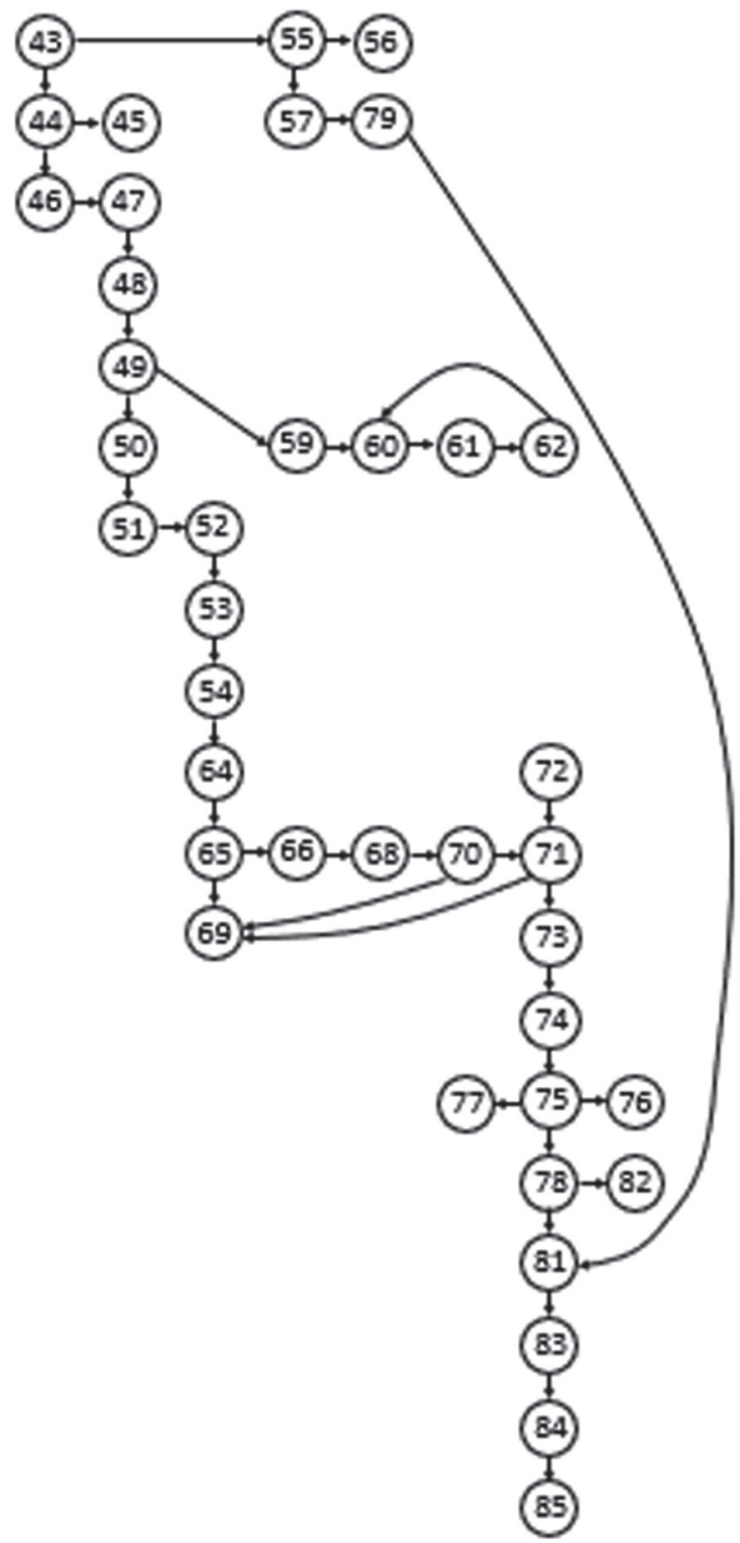

Figure 4. Juliana's causal chain showing the connection of events in the moment she published her first paper. 
43 después entonces empecé a estudiar la maestría y

44 estando en la maestría pues había que escribir muchos papers, ¿no? así como les toca a ustedes.

45 entonces, en cada materia había que escribir papers y

46 allí la situación fue diferente porque pues ya ya me empe...,

47 o sea, valoraban primero mucho lo que yo escribía

48 entonces me iban corrigiendo cosas y bueno

49 y un profesor, que se llama $\mathrm{XXXXXX}^{6}$ que fue mi profesor de una materia que se llamaba testing, evaluation and testing,

50 y nos puso hacer un small-scale research project.

51 Y yo lo hice con una compañera con unos niños de un colegio rural y

52 era básicamente mirar qué tanto lo que proponía la institución tenía que ver con lo que proponía la profesora y con lo que los niños necesitaban. Era como evaluar esas tres cosas y mirar, pero una cosa muy pequeñita

53 entonces hicimos eso

54 entonces al final del semestre entonces

55 ah, pero bueno antes de decir todo lo que pasó a final de semestre, esa era la época en que en Colombia apenas las revistas, porque Colombia tuvo una época en que la gente escribía para otras editoriales o porque querían escribir

56 pero, las revistas no eran famosas, no había revistas en nuestra área. No había revistas en inglés, mejor dicho,

57 sino que esa fue la época, estamos hablando de hace 20 años, uysh, salieron las revistas a florecer en nuestra área

58 y este profesor que te cuento entonces, había una revista de la Universidad XXXXX que se llama Journal XXXX y estaba naciendo la revista. Este era su número dos

59 y este profesor entonces cuando vio nuestro trabajo llegó y dijo

60 él nos quería mucho a mi compañera y a mi

61 que éramos las más jóvenes del curso, porque molestábamos mucho en clase

62 éramos unas niñas, es que yo tenía 20 años, éramos unas niñas en clase, y era más joven que yo, entonces éramos muy chiquitas

63 y él nos quería mucho

${ }^{6}$ We used XXXXX to replace the names of the teachers, universities, and journal to maintain the narrator's anonymity. 
64 y nos dijo, no, por qué no publican ese trabajo que ustedes presentaron. Por qué no lo mandan a Journal XXXXX para que lo publiquen

65 y nosotras simplemente no lo podíamos creer, quedamos como ¿huh?

66 o sea, realmente ¿esto vale la pena? Que publiquemos, pues no, unas cosas que habíamos hecho como tan,

67 pues sí lo habíamos hecho a conciencia, ¿no? Pero no era la gran investigación ni nada

68 entonces hicimos el ejercicio y lo pasamos a Journal XXXXXX

69 tal cual él no lo devolvió

70 porque hasta ese momento no habíamos entendido

71 como era la primera vez que íbamos a escribir algo formal, digamos, diferentes a los trabajos de la universidad

72 no habíamos entendido que la forma de escribir un artículo no era la misma que uno hace un trabajo, una cosa es un trabajo y otra cosa es un artículo

73 entonces lo pasamos así

74 nos lo evaluaron

75 y nos lo devolvieron con 25,000 correcciones, con muchas correcciones

76 muy amables

77 pero con muchas correcciones, muchas, muchas

78 y nosotras vimos eso y dijimos no esto

79 pero resulta que la editora de la revista, la profe XXXXXXX, que todavía es la editora de la revista, XXXXX era profesora de nosotros también en la maestría

80 entonces cuando nosotras recibimos todo eso

81 llegó y dijo ya se los devolvieron con la evaluación, espero que lo corrijan y me lo vuelvan a mandar

82 entonces eso como que nos forzó, porque nosotras cuando vimos las evaluaciones, las correcciones, dijimos como que ya dejemos así

83 pero cuando ella nos dijo eso, dijimos como le vamos a quedar mal a la profe

84 y bueno lo arreglamos

85 y finalmente ese fue el primer artículo que yo escribí en mi vida 
In her story, two key agents appeared as motivators in her writing process. The first was the professor who asked her to send her paper to Journal XXXX (line 49). She went back in her story to provide information as to why he had motivated her and her classmate (lines 60, 62, \& 63). His appreciation for the narrator and her classmate caused him to invite them to send their paper to Journal XXXX. She explained the submission process, particularly how she had received many corrections. Given the high volume of edits needed to publish, she and her classmate decided not to fix the paper. The second agent was another teacher (line 79), who also happened to be the editor of Journal XXXX. After seeing that the narrator and her classmate had submitted their paper, the teacher expected them to fix the paper and resubmit. Not disappointing the teacher (lines $82 \& 83$ ) became the main cause for fixing the paper (line 84), which led to a successful publication (line 85).

In terms of education and teaching practices, we identified a teacher who has adapted her teaching methods as a cause of traumatic childhood events. Juliana's ways of teaching are inclusive and promote non-traditional forms of writing. The narrator's resilience in her field, despite negative causality in central events, demonstrated her vocational spirit to teach and research. Later on, she mentioned how her doctoral program helped her break out of structured ways of thinking. In turn, she has become an advocate of researching and writing from our own individual perspectives and positions. She mentioned that her doctoral program,

[has helped me now that I direct theses to not be so square about it, instead I tell them (students) that there are many possibilities]. (Juliana, Personal interview)

In failing to have a positive central event in her childhood that shaped her writing, she adapted her own way to write within her context. Her own writing style has helped shaped other writers in the field, in addition to promoting new ways to look at research and writing. Her context has also allowed her to question standardization in academic writing and research.

\section{Discussion and conclusions}

When we began this study, we were unsure what we would discover. The narrator and their stories extended way beyond the limits of our initial research question: What do women's narratives reveal about the central events and causal connections in their process as writers for academic purposes? To answer the question, the three female scholars revealed that the key ingredients in their process as writers were social interactions with other agents and the context. 
All three women mentioned agents in their process as writers. In Persona's central event, her interaction with her director helped shape her research. Even in the interview, Persona wrote out figures and lines to explain her process as a writer. For Mik, it was her meaningful interaction with her father when she was a child. Through her father's poetry readings, Mik discovered a love for writing that she carries with her today. Her father's readings and knowledge of languages were also pivotal in her decision to become a language teacher. As for Juliana, agents were present in both positive and negative causalities. During her childhood and undergraduate program, the key agents were her teachers, who unfortunately mistreated her. Their actions caused negative effects, which were later displayed in her lack of confidence as a writer and in her choice of teaching practices. Later on, her teachers in the master's program, as well as her doctoral program, gave her motivation and self-confidence to write and publish.

From all of the three women, we see the profound implications teachers and parents have on the writing process. Additionally, we noticed that all three women relied on validation from an agent to verify that they were on the right path. Among all the women, the central agent happened to be a mentor who has had more experience in the field. Persona had her director, Mik recognized her father, and Juliana talked about her teachers and mother. These mentors provided the narrator with guidance, as well as motivation to continue in the writing process.

The second aspect that emerged from the narratives was the importance of the context. Both Persona and Juliana explicitly mentioned how the context shaped research and writing. For Persona, the context made a big difference in the discussion of results. Without the necessary equipment and funding, she is forced to turn down her undergraduate students' requests to use particular methodologies. She also has to constantly readjust her research. She may have started out with five figures (five methodologies), but her context limits her to only three figures. Persona believed that this has profound implications when publishing given that the validity of the discussion could be questioned if it lacks methodologies.

In addition, other cultural factors exist within the sciences in Colombia, which she mentioned as issues in the dissemination of research. For example, Persona's belief of insignificance associated with being Hispanic (and possibly a woman in the sciences) prevented students from writing about their research. Secondly, she mentioned that Colombian professors in the field are closed off to providing information when they have reached a sense of grandeur. She mentioned the following,

[In this country there still exists a lot of difficulty (dissemination of knowledge). In other words, here a professor can do a doctorate program at the Universidad XXXXX and believes that his doctorate makes him a genius. And I say, you haven't done anything. And the student goes and asks him a question on how to write this or that. And he doesn't respond because he knows too much]. (Persona, Personal interview) 
From interviewing Persona, we noticed that the culture of the context sets the stage for many power relationships that shape writing. These power relationships, which can even extend beyond the country, halt the dissemination of research within the country. In addition, she mentioned that local journals provide limited information on what should be changed during the evaluation process.

In the case of Juliana, her master's program was being carried out at the same time Colombian English and language journals were emerging. The presence of local language journals has allowed many students and professors to make their work visible. These journals seem to embrace new waves of thought, which has made an impact on teaching in other countries as well. Unlike the culture behind writing in the sciences, writing in local language journals builds the writer's confidence to continue publishing. They strive to show the writer's work in the academic arena, which is evident in relationships between authors, evaluators, and style correctors. Juliana even mentioned that the evaluators were nice despite all the corrections, and she even had a one-on-one interaction with the editor of the journal. Juliana further stated that,

[once you are an evaluator, you recognize a lot more, many things, and you become humbler]. (Juliana, Personal interview)

Once again, we see a different side of research that is focused on nurturing the writer-researcher. Certainly, local journals are promoting, questioning, and negotiating the standardization of research and Academic English. As Mauranen, Pérez-Llantada, and Swales (2010) mentioned, "Academic language conveys new, often abstract, concepts and thoughts, which participants also co-construct in their discussions and argumentation" (p. 640). Therefore, academic writing is being transformed by society, interactions, and the writers themselves at a local level.

Finally, it is worth mentioning that central events and their causal connections are crucial in the process of writing. They shape the writer's identity and teaching practices. Of course, these central events and causal connections do not exist in a vacuum. Instead, they are aided by the narrators, agents, and social context. Much work is still left to be done in the fields of academic writing, the individual writing process, and causality. Though the narrators have expanded our insights on some of the cultural factors that shape writing, each factor could be explored through further interviews. Additionally, we can continue using narratives to understand other writing processes, such as that of foreign language undergraduates, research group investigators, and directors within the local context. This could provide more information on how the language gap is being bridged among local researchers.

From the narratives, we also noticed that each research field has a distinct culture, which is worth exploring. Even within the same field of study, gender, status, and age seem to affect the individual's writing process. Of course, these factors also determine the researcher's visibility, especially when we continue to see women and 
minorities underrepresented in academia. Ethnographic studies could help determine the implications that these cultural factors have on the dissemination of knowledge, publication acceptance, and transformative change in research. In addition, further research is required in the field of language teaching, given that the agent is a major part of the individual's writing process. Ultimately, research in language teaching could help yield more constructive and transformative ways to teach academic writing that question traditional, standardized methods. In doing so, the idea would be to promote the author's voice, while introducing the author to the socio-cultural components that make each writing style unique. A greater reliance on the author's individual writing process rather than prescribed writing methods could result in longer lasting motivation. As you can see, the work is plenty, which is why this ending can only be the beginning. 


\section{References}

Anderson, C. E., \& Cuesta-Medina, L. (2019). Beliefs and practices concerning academic writing among postgraduate language teacher trainees. Íkala, Revista de Lenguaje y Cultura Medellín, 24(1), 29-49.

Albarillo, F. (2014). Language in social science databases: English versus non-English articles in JSTOR and Scopus. Behavioral \& Social Sciences Librarian, 33(2), 77-90.

Bamberg, M. (2010). Narrative analysis. In H. Cooper (Ed.). APA handbook of research methods in psychology. American Psychological Association (APA).

Barletta, N. P. (2007). English teachers in Colombia: Ideologies and identities in academic writing [Doctoral dissertation, University of Arizona]. University of Arizona University Libraries.

Berger, R. (2015). Now I see it, now I don't: Researcher's position and reflexivity in qualitative research. Qualitative research, 15(2), 219-234.

Cárdenas, M. (2014). Publishing and academic writing: Experiences of authors who have published in Profile, PROFILE Issues in Teachers' Professional Development 16(2), 11-20.

Cepeda, L. \& Barón, J. (2012). Segregación educativa y la brecha salarial por género entre los recién graduados universitarios en Colombia (Documentos de trabajo sobre economía regional, 162). Cartagena: Banco de la República de Colombia

Cixous, H. (1976). The laugh of the medusa (K. Cohen \& P. Cohen, Trans.). Signs, 1(4), 875- 893.

Clandinin, J. \& Connelly, M. (2000). Narrative Inquiry. Experience and Story in Qualitative Research. San Francisco, California: Jossey-Bass.

Colciencias. (2017). Grupos de investigación reconocidos por Colciencias. Retrieved from https://www.colciencias.gov.co/la-ciencia-en-cifras/grupos

Connelly, F. M., \& Clandinin, D. J. (2006). Narrative inquiry. In J. L. Green, G. Camilli, P.Elmore (Eds.), Handbook of complementary methods in education research ( $3 \mathrm{rd}$ ed., pp. 477 - 487). Mahwah, NJ: Lawrence Erlbaum.

Correa, D., \& Echeverri, S. (2017). Using a systemic functional genre-based approach to promote a situated view of academic writing among EFL pre-service teachers. HOW, 24(1), 44-62. https://dx.doi.org/10.19183/how.24.1.303

Díaz, C. (2010). Hacia una pedagogía en clave decolonial. Entre aperturas, búsquedas y posibilidades. Tabula Rasa, (13), 217-233. 
Fine, I., \& Shen, A. (2018). Perish not publish? New study quantifies the lack of female authors in scientific journals. The Conversation. Retrieved from https:// theconversation.com/perish-not-publish-new-study-quantifies-the-lack-offemale-authors-in-scientific-journals-92999

Gómez, J. (2011). Teaching EFL Academic Writing in Colombia: Reflections in Contrastive Rhetoric. PROFILE Issues in Teachers' Professional Development, 13(1), 205-213.

Guba, E. G. \& Lincoln, Y. S. (2005). Paradigmatic controversies, contradictions, and emerging confluences. In N. K. Denzin \& Y. S. Lincoln (Eds.). The Sage handbook of qualitative research ( ${ }^{\text {rd }}$ ed., pp. 195-196.). Thousand Oaks, CA: Sage.

Granados- Beltrán, C. (2016). Critical Interculturality. A Path for Pre-service ELT Teachers. Íkala, Revista de Lenguaje y Cultura, 21 (2) 171-187

Hedge, T. (2005). Writing. Oxford: Oxford University Press.

Heidegger, M. (2003a). El concepto de tiempo. Madrid: Trotta

Kumaravadivelu, B. (2014). The Decolonial Option in ELT. Can the subaltern act? TESOL Quarterly(50), 67-85.

Lea, M. \& Jones, S. (2011). Digital literacies in higher education: exploring textual and technological practice. Studies in Higher Education, 36(4), 377-393.

Maldonado-Torres, N. (2010). On the coloniality of being: Contributions to the development of a concept. In W. Mignolo \& A. Escobar (Eds.), Globalization and the decolonial option. (pp. 94-124). New York, NY: Routledge.

Mauranen, A., Pérez-Llantada, C., \& Swales, J. M. (2010). Academic Englishes: A standardized knowledge? In A. Kirkpatrick (Ed.), The Routledge Handbook of World Englishes (634-652). London, UK: Routledge

Mason, J. (1996). Qualitative researching. London: Sage.

Maturana H. R. (2007). systemic versus genetic determination. Constructivist Foundations, 3(1), 21-26.

Mignolo, W. (2011). The Darker Side of Western Modernity: Global Futures, Decolonial Options. Durham: Duke University Press.

Mitchell, V. (1996). Rethinking foreign language writing. Oxford: Oxford University Press. 
Mur Dueñas, M. P. (2012). Getting research published internationally in English: An ethnographic account of a team of Finance Spanish scholars' struggles. Ibérica, (24), 139-155.

Ndlovu-Gatsheni, S J. (2018). Epistemic freedom in Africa: Deprovincialization and decolonization. London and New York: Routledge.

Porter, S. (1993). Nursing research conventions: Objectivity or obfuscation? Journal of Advanced Nursing, 18, 137-143.

Ramos, B., Quintero, E., \& Moreno, N. (2013). Dialogue journals: A pedagogical strategy to analyze students' English writing development. Enletawa, 6, 9-20.

Quijano, A. (2000). Coloniality of power, Eurocentrism, and Latin America. Nepantla: Views from South, 13, 533-580.

Quilindo, C., Calvache, J., \& Delgado, M. (2018). Scientific and academic production and visibility of the Faculty of Health Sciences of Universidad del Cauca. Revista de la Facultad de Medicina, 66(4), 557-563,

Restrepo, E., \& Rojas, A. (2010). Inflexión decolonial: Fuentes, conceptos y cuestionamientos. Cauca: Editorial Universidad del Cauca.

Ricoeur, P. (1996). Sí mismo como otro. México: Siglo XXI editores.

Richards, K. (2009). Trends in qualitative research in language teaching since 2000. Language teaching, 42(2), doi 10.1017/S0261444808005612

Seloni, L. (2014). "I'm an artist and a scholar who is trying to find a middle point": A textographic analysis of a Colombian art historian's thesis writing. Journal of Second Language Writing, 25, 79-99.

Shannon, S. (2011). A guide to academic and scholarly writing. United States: Baldwin Book Publishing.

Trabasso, T. \& Sperry, L. L. (1985). Causal relatedness and importance of story events. Journal of Memory and Language, 24, 595-561.

Trabasso, T. \& Van den Broek, P. (1985). Causal thinking and the representation of narrative events. Journal of Memory and Language, 24, 612-630.

Van den Broek, P., Linzie, B., Fletcher, C., \& Marsolek, C. J. (2000). The role of causal discourse structure in narrative writing. Memory \& Cognition, 28(5), 711-721.

Van Manen, M. (1997). Researching lived experience: Human science for an action sensitive pedagogy. London, ON: The Althouse Press. 


\section{Authors}

* Bertha Ramos-Holguín holds a Ph.D. in Education Sciences from Universidad Pedagógica y Tecnológica de Colombia (UPTC), an M.A in Applied Linguistics to the Teaching of English as a Foreign Language and a B.A in Modern Languages from Universidad Distrital Francisco José de Caldas. She is currently a researcher and an English professor in the School of Languages at UPTC. As part of the research group TONGUE, she has authored and coauthored research academic papers and English textbooks.

ORCID ID: https://orcid.org/0000-0003-4468-1402

Anna Carolina Peñaloza Rallón holds a master's in Language Teaching from the Universidad Pedagógica y Tecnológica de Colombia (UPTC) and a BS in Environmental Science from the University of Arizona. She is currently a researcher and a professor in the master's in Language Teaching from UPTC. She teaches a course in Second Language Acquisitioning and Academic Writing. She is part of the research group TONGUE. She is an advocate of critical pedagogies and social equity in the community.

ORCID ID: https://orcid.org/0000-0002-6394-4346

How to reference this article: Ramos-Holguín, B., \& Peñaloza-Rallón, A. C. (2020). Central Events and Causal Connections: A Narrative Study on the Writing Process. GIST - Education and Learning Research Journal, 20, 33-63. https://doi.org/10.26817/16925777.770 